\title{
CHIEFTAINCY IN NORTHERN TOGO
}

By E. A. B. van Rouveroy van NieuwaAl

\section{Introduction}

Legally, the administration of justice in Togo is limited to the jurisdiction of the courts of modern law (Tribunaux de Droit Moderne) and the courts of customary law (Tribunaux Coutumiers). Both types of courts are staffed by trained judges with their own assistants, together with numerous formalities, dossiers, typewriters, etc; in effect, these are the types of courts that are common in the more industrialized countries. The judiciary in Togo is in many respects patterned on that of the French model - even the judge's robe ${ }^{\mathbf{1}}$.

Thisdual judicial system, however has been a thorn in the side of Togolese lawyers for years. It is a situation that does not seem appropriate to a modern world where each citizen is equal before the law - whether his case be tried within the court of modern law or one of customary law - and where, ideally, then, there ought to be a single system for the administration of justice. Thissingle national judicial system ought to be enforced by one type of court as well ${ }^{2}$. It is a strugglesimilar to what waged elsewhere in Africa for many years now, and it has in some cases led to the abolition of the pluralistic colonial judicial system.

Now, almost twenty years after having become independent, this desire for a single judicial system is also making itself felt in Togo; there appear to be plans to abolish the existing dual adjudication of justice ${ }^{\mathbf{3}}$.

Broadly speaking, however, there is yet a third category included in the judicial system. Although it is only mentioned in passing by the legislature, it nevertheless plays an especially important role in daily legal affairs. This third type of justice is the dispute settlement by the local chief (chef coutumier). In the legal terminology, the legislature carefully uses phrases such as "the settling of dispute", or the "reconciliation of the disputing parties in this connection", and not adjudication. Although there is a difference between reconciliation and adjudication for our own Western norms, in tribal concepts of justice such differences may not play such a role.

In fact, we know from our own research in Northern Togo that the anufò people refer to the settlement of disputes by the most important traditional leader, the paramount chief, as adjudication, in exactly the same way as they do for the settlement of disputes by the lowest official court, the Tribunal de Première Instance, mostly indicated by its president, the Juge de Paix 4 .

The juridical position of the local chief in the French colonial period was never completely set. This was left to the governors-general (gouverneurs-général), who repeatedly issued circulars on this subject, taking up the position of the local chief5.

Whatever else can be deduced from the French colonial policy with regard to the local chief, it is in any case clear that the colonial authorities thoroughly understood that without the local chief's aid, a native administration was impossible. Despite this, they failed to conclude

1 Van Rouveroy van Nieuwaal, E. A. B., 1976, A la recherche de la Justice, quelques aspects du droit matrimonial et de la justice coutumière au Nord-Togo, Leiden-Hasselt, p. 50.

2 Laloum, J. D., 1967, Manuel du Juge de Paix, Editogo, Lomé, p. 20.

3 Van Rouveroy van Nieuwaal, E. A. B., Droit Moderne et Droit Coutumier au Togo, Recueil Penant, 1975, no. 747, p. 5-18.

4 Van Rouveroy van Nieuwaal, E. A. B., Unité du droit ou diversité du droit, bases juridiques du droit coutumier a u Togo, Verfassung und Recht in Ubersee, 12 (1979), p. 143-158. 
that this aid could not be given unless the local chief had a substantially secure juridical and financial position.

In Togo, as well, this matter is hardly regulated at all. There are two "arrêts", one from 1949, and the other from $1958-1959^{6}$, that generally deal with the extent to which the local chief, as civil servant, comes directly under the control of the central authorities, and as such, can be legally prosecuted for administrative offences: in other words, to what extent can he, like any other government representative, be held responsible and fined by an administrative judge. The present Togolese government competes for the goodwill of the local chiefs just as the colonial administration did. The chiefs are organized, on government initiative, into an alliance (Union des Chefs Traditionnels). They are regularly summoned together, and at these assemblies they are presented with the question to what extent do they support government actions. This situation is reminiscent of Ian Smith's policy in 1964-1965 in ZimbabweRhodesia when he asked the Rhodesian local chiefs to support his lead in leaving the Commonwealth ${ }^{7}$.

\section{The functions of the local chief}

In considering the several functions (I restrict myself to the legal and political functions) a distinction should be made between two aspects:

- his functions as tribal adjudicator;

- those functions that the government delegates to, or expects the local chief to perform. With regards to the first mentioned functions, it may be useful to bear in mind van Vollenhoven's comments, a pre-eminent Dutch scholar on Indonesian customary law (adat law):

In the first instance, to lend support to the observance of customary law (adat) . . ; furthermore, they act as living archives of customary law through the things they witness, participate in, pass on to their sons . . .; finally, a right to settle disputes on the principles of customary law ${ }^{8}$.

If we focus on the last part of this description, we see that French colonial law put rather an immediate end to the thoroughgoing judicial powers of the local chief, powers which had earlier existed in Togo under the German colonial government (1884-1914) ${ }^{9}$. After 1914, the French legislature issued a series of decrees regulating the behaviour of local chiefs in daily life, and in 1933, it reduced their authority to "conciliation", a solely civil judicial power. It was emphasized, however, that a conciliation brought about by a chief did not prevent the contesting parties from using the official judge $\mathbf{e}^{10}$.

In 1961, the Togolese legislature went still further by not even including the conciliatory function in its Law concerning Judicial Organization ${ }^{11}$. This law regulates the relationship between modern law and customarily law, and no longer even mentions the actions of the local chief. Thus, in a strictly legal sense, the predominant opinion among lawyers is that the local chief is merely a government civil servant, and not a judicial authority. But in the affairs

5 Cornevin, R., L'évolution des chefferies dans l'Afrique noire d'expression française, recueil Penant, 1961 , p. 379 and p. 539.

6 Arrêt of the second of October, 1949, J.O. of Togo, 1949, no. 1145; arrêt no. 59-121 of the third of August 1959.

7 Holleman, J. F., 1969, Chief, Council and Commissioner, Assen, p. 347.

8 Het Adatrecht van Nederlandsch-Indië, part II, Leiden, 1931, p. 247-256.

9 Van Rouveroy van Nieuwaal, E. A. B., Le droit coutumier dans la période allemande au Togo, in: Verfassung und Recht in Ubersee, to be published.

10 Chabas, J., La justice de droit local en Afrique occidentale, Annales Africaines, 1955.

11 J.O. 1961, no 71-17. 
of daily life, this legal view plays only a small role. In large measure, the people turn to their own local chiefs to find the most appropriate solution in cases of conflict. The government also knows that the actions of the local chief are important in daily judicial affairs, so much so, that as a result of such actions, the office of the Juge de Paix is not flooded by disputes with which this judge might not be able to deal ${ }^{12}$.

This situation in which there is a formal denial of this important function that belongs to the local chief is not typical of Togo alone. Harrell-Bond ${ }^{\mathbf{1 3}}$, for instance, reports the same situation to be true of Sierra Leone. It probably also relates to the belief that the local chief ought not to have too much power within the political sphere, and that certainly not if the local chiefs already have great authority among the people. This is true, for example, in the case of a paramount chief in southern Togo, where the government-including the president himself - is forced to take into account the whishes of this chief when making its decisions. Moreover, there is also experience with bad chiefs who only view the settlement of disputes as a primary source of income - together with all the abuses that this entails.

However important the settlement of disputes is, this is not the local chief's only function ${ }^{14}$. His concern and support for the observance of customary law, as van Vollenhoven puts it, must also not be forgotten. With this phrase, van Vollenhoven indicated one of the local chief's especially important functions; his very presence at many matters other than disputes and lawsuits - such as, for instance, concluding an agreement, contracting a marriage, etc. for the very fact of his presence serves as a better guarantee for compliance with the agreement. Or, as van Vollenhoven describes it:

"It is not (here) primarily, or even principally, a matter of substantiating facts, rather, the element that comes to the fore as of far greater importance is that the traditional authorities, by their presence without protest, by their co-operation, as it were, tacitly imply that the matter concerned, that the transaction being concluded accords with tribal law, or that it does not go counter to tribal customs".

And the following example, taken from our own investigations supports this.

The morning following the consummation of her marriage, among the Islamic Anufòm, it is customary for a woman to go to the paramount chief of the place where, two days previously, her marriage had formally been concluded by an Imâm. Before placing her thumbprint on the civil contract the bride, still in her bridal finery, kneels in front of the paramount chief (for he is concerned with some civil registration). Thereupon the chief asks her: "Do your not reject this marriage?" (akete ma adya?). While at the same time carelessly holding a whip in his hand, three times he poses this question to her - in a tone whose seriousness cannot be misinterpreted by the woman. He thus means to impress upon her that if she runs away, she will be whipped. In such an event, she would later be liable to the charge of adultery. According to the chief, the intent is that the woman cannot then afterwards claim that she had been forced into the marriage, since she had indeed had the opportunity to make it known if marriage had been against her wishes.

This example can be extended over countless instances - for example, in the area of land transactions. The presence of the chief at agreements concerning the use or transfer of land is

\footnotetext{
12 Van Rouveroy van Nieuwaal, E. A. B., Terre au Nord-Togo-relation entre Ngam Ngam et Anufò en matière foncière, in African Perspectives no. I, 1979, edited by the author. This volume of African Perspectives deals with reform of land tenure law in West Africa and is based upon the contributions to the international seminar in Lama-Kara, North Togo, held in October 1978.

13 Harrel-Bond, B. E. \& Rijnsdorp, U., Family-Law in Sierra Leone, Research Report, Afrika-Studiecentrum, Leiden, 1975, p. $108-110$.

14 See my social documentary film about dispute settlement of the court of the Paramount Chief of the Anufò: SHEREA, 1975, 24 min., distributed by the Foundation for Film \& Science, Utrecht, The Netherlands; English and French version.
} 
in fact an absolutely necessary precondition, recognized as such even by the government ${ }^{15}$. This once again underlines the fact that the role of the local chief is not limited solely to arranging settlement, mediation, or adjudication.

For the Togolese government, however, the local chief is primarily an administrative adjunct. He was often appointed during the colonial period ${ }^{16}$, and was given the responsibility for tax collecting, keeping the civil records (usually under the most primitive conditions, and without trained personnel), and finally, was also required to maintain public order. It is primarily this latter that becomes a substantial task in a changing society, where old, trusted ways and attitudes must be abandoned, and where the new generation no longer unquestioningly accepts the authority of their elders. One of the continuing concerns of the local chief is the practice of setting fire to the fields after the harvest. For as far back as anyone can remember this has been done in order to promote the fertility of the land. Although such "feux de brousse" (forest fires) have been forbidden for decades now (since 1929), they still take place, wreaking great damage to both flora and fauna. The most extreme way of dealing with this is to hold the local chief responsible, and if he cannot show who the true guilty parties are, then he is locked up in their stead.

The appointment of a local chief takes place according to traditional tribal rules, at least insofar as these exist ${ }^{17}$. The actual appointment, however, as well as the right to the salary that goes with it, is completely in government hands. It is controlled by the Minister of Interior Affairs, under whose jurisdiction the local chief falls. Moreover, the government does not hesitate at all to push its own candidate, both in the elections ${ }^{\mathbf{1 8}}$ and for the appointment. My film, A TOAD IN THE COURTYARD ${ }^{19}$, clearly shows, however, in what way the people and their traditional leaders, through internal manipulation know how to counter the central government's ascendancy, and thereby manage to have their own candidate appointed. It is nevertheless the case that at present, a candidate needs government support if he wishes to be chosen and appointed.

This is not at all a new state of affairs. Busia, the former President of Ghana, describes in great detail how the English colonial administration in the Ashanti kingdom appointed, dismissed, and retained the paramount chiefs - often against the wishes of certain groups ${ }^{20}$. It is clear that the local chief has become completely subservient to the larger government authority, and has as his direct superior the head of the district (chief de la circonsciption).

\section{Area of Tension between Local Chiefs - local government and the administration of jus- tice}

In order to understand why possibilities for tension and conflict are built into the relations between local chief and government, it will be necessary briefly to discuss the administrative division of Togo.

\footnotetext{
15 Van Rouveroyvan Nieuwaal, E. A. B., The plot of the sophisticated son-in-law: disparity between old and new ways of establishing rights over land in N'zara, North Togo, in: Kroniek van Afrika, now: African Perspectives, 1975, no. I, p. 48-59, or in French: Qui Terre a, Guerre a: disparitéentre le droit foncier moderne et le droit foncier coutumier à N'zara au Nord-Togo, Recueil Penant, 1977, no. 756, D. $149-169$.

16 Geschiere, P., Traditional elders, colonial chiefs and modern intellectuals, Kroniek van Afrika, 1975, no. II, p. 96-98.

17 Articles 7 and 8 of the "arrêt" from 1949, see also note 6.

18 Van Rouveroy van Nieuwaal, E. A. B., La Justice Coutumière au Nord-Togo, Recueil Penant, 1976, no. 751 , p. 50.

19 A documentary film about the unhappy position of the Paramount Chief in North Togo being a servant of two masters: the central government and his own tribal community, 1979, 25 min. distributed by the Foundation for Film and Science, Utrecht. The Netherlands, English and French version.

20 Busia, A. K., 1961, the position of the chief in the modern political system of Ashanti, O.U.P.
} 
This is based upon the colonial division that had been made by the French authorities. The most important administrative unit is the province (circonscription), subdivided into smaller parts or cantons, which are, in turn composed of several villages. The district head (chef de la circonscription) is at the head of all these units combined.

In most instances ${ }^{21}$ these administrative units have a local chief, and the hierarchy of authority is:

village chief;

cantonal chief;

paramount chief.

The local chiefs are responsible to the district head, while the lesser local chiefs also recognize the paramount chief as their supreme traditional ruler.

The district head never comes from the area over which he governs. His position can be best compared with that of the French administrator, the commandant de cercle. His position is hardly enviable, when the ease with which he can become entangled in the snares and pitfalls that the people and their leaders set for him is considered. In the Mango district alone, in the past 10 years I have seen about six district heads totter and then be discharged from their office, because they had been too closely involved in various, diverse local interests. The exparamount chief, $\mathrm{Na}$ Tyaba Tyekura, was also involved in this when, in 1977, rich merchants from neighboring Ghana tried to convince the Imâm of N'zara (= Sansanné-Mango) to influence the pilgrims to Mecca that year to pray in Mecca for Allah's help in bringing down the Togolese government. This caused unrest throughout all of Togo, because many Imâms were involved in it, and thereby lost their function and office as religious leader. Thus, the then Imâm of N'zara also received a letter with money enclosed, requesting him to divide the money among the pilgrims to Mecca. A part of it was intended for the paramount chief. The Imâm informed the chief about this, but the latter immediately rejected the offer, because of its potentially explosive character. Nevertheless, the Imâm delayed just a bit too long before bringing the matter to the attention of the district head, and thereby made himself suspect as being among those who were plotting to bring down Eyadéma, the President of Togo. As a result, the Imâm was directly taken into custody, and was only freed a year later; furthermore, the affair caused him to lose both his function and his office.

For the district head this was a precarious business, as well. In any event, it placed him in a difficult situation with respect to the paramount chief and the powerful family from which Imâms were traditionally chosen. But for the paramount chief, $\mathrm{Na}$ Tyaba Tyekura, it was just the beginning of a series of difficulties which ultimately led to his deposition in December, 1977 (see note 19).

The administrative setup is rather easy to show schematically:

\begin{tabular}{l|l}
\hline $\begin{array}{l}\text { The Minister of Interior Affairs } \\
\text { District Head }\end{array}$ & Central government \\
\hline $\begin{array}{l}\text { Paramount Chief } \\
\text { Head of a canton } \\
\text { Village head }\end{array}$ & $\begin{array}{l}\text { acknowledged tribal } \\
\text { chiefs }\end{array}$ \\
\hline
\end{tabular}

21 Van Rouveroy van Nieuwaal, E. A. B. \& van Rouveroy van Nieuwaal-Baerends, E. A., 1976, Ti Anufò-un coupd'oeil sur la société des Anufòm dans le Nord du Togo, Leiden-Hasselt, p. 18. 
The local chiefs who are subordinate to the paramount chief actually serve two masters: on the one hand they are responsible to their highest traditional leader, and on the other, the central government also expects explicit loyalty from its local representative. Moreover, the paramount chief's position is very ambivalent as well, for, while his title rests upon a traditional basis ${ }^{22}$, and his own people expect that he will remain loyal to the principles of the society, he must also conform to the (high) expectations that the government now requires of him. In implementing unpopular decisions, he risks losing the trust and support of his people; but on the other hand, he jeopardizes his position in the eyes of the government if he is not sufficiently loyal to the central authorities. Many a chief does not possess enough skill at balancing to enable him to retain his equilibrium on such a tightrope ${ }^{23}$.

One extremely thorny question, for example, is the present requirement of compulsory participation in every party assembly. Insufficient participation in Party assemblies (Rassemblement du Peuple Togolais), that is not enthusiastic enough results in criticism of the tribal chief by the government, which then accuses him of disloyalty. But, on the other hand, he can also count on dissatisfaction among his people when he is away at Party assemblies, because he is then less available for to consult on diverse and varied matters.

Besides the continual threat of conflict between government and local chief - for, in many instances, their interests are not parallel - there is a less obvious, but nonetheless significant area of conflict between the paramount chief and the lowest official court of customary law (the Tribunal Coutumier de Première Instance). The Tribunal was set up under the Loi relative à l'Organisation of the 12th of June 1961 and is thus an official court. It is staffed by an African lawyer (trained in French law) known as the "Juge de Paix", who is advised, but not bound by two African assessors. The competence of the Juge de Paix is restricted to civil matters (,,en matière civile et commerciale") and to minor criminal cases which the Juge de Paix tries without assessors. In general the territorial jurisdiction of this kind of court is limited to one circonscription.

The Juge de Paix and the paramount chief sit a stone's throw from one another, territory and settle disputes between people who live in the same territory (the Mango circonscription). However, not only is there no contact between them, they cannot stand the sight of each other. They repeatedly accuse one another of "class justice", "misuse of power", etc. This, at least, had been the situation at the time of my investigations (1969-1971;1977-1978). This tension is itself quite understandable, given for example, the Anufò system of exchange women divorce, and the restitution of marriage payments. The Juge de Paix and the paramount chief have different viewpoints concerning these matters ${ }^{24}$. The differences may be attributable to different cultural backgrounds, education and the positions of the Juge de Paix and his traditional counter part, the paramount chief: the first represents "modern" and mostly western law (which in official and educated circles is also regarded as "progressive"), while the paramount chief represents traditional rules and values. This does not mean, however, that in his decisions the paramount chief ignores rapidly changing ideas about an institution like marriage, such as the fact that nowadays a woman cannot be forced to marry a man whom she does not want. On the other hand, in certain situations the Juge de Paix must apply customary law, and cannot act in utter disregard of traditional ideas. Nonetheless, there is a tension between the Juge de Paix who is directed by the central government to introduce new institutions, and the conservatism of the paramount chief.

22 Van Rouveroy van Nieuwaal, 1976, La Justice coutumière au Nord-Togo, Recueil Penant, 1976, no. 751, p. 35-70.

23 Holleman, 1969: 117-118.

24 Van Rouveroyvan Nieuwaal, E. A. B. \& van Rouveroy van Nieuwaal-Baerends, E. A., Toclaim or not to claim, changingviews about the restitution of marriage prestations among the Anufom in North Togo, in: Law and the Family in Africa, ed. S. A. Roberts, 1977,The Hague, p. 93. 
Consequently, the two legal institutions are more or less in competition with each other. Since both are available to men and women looking for a favorable disposition of their disputes, there is an excellent opportunity for many a litigant to play off these institutions against each other. At the same time, litigants are the means by which the paramount chief and the juge de paix compete with each other: thus every case is potentially an affair of four parties engaged in mutual manipulation. At any event, the Juge de Paix and the paramount chief must always each take account of the existence and views of the other ${ }^{25}$.

If we were to summarize the position of the paramount chief in Northern Togo, no better description could be given than that of $\mathrm{Na}$ Tyaba Teykura himself, the ex-paramount chief of the Anufòm; "before the arrival of the white man, my position as paramount chief waslike a woman who carries her jug of water on her head. While she carries it, she walks without any problem, but in entering her hut she must lift the jug off her head and carry it in front of her stomach. It is that moment that any misstep would be fatal to her equilibrium. Such is my position in these days". 